This item was submitted to Loughborough's Research Repository by the author.

Items in Figshare are protected by copyright, with all rights reserved, unless otherwise indicated.

\title{
Delivering localism: the critical role of trust and collaboration
}

PLEASE CITE THE PUBLISHED VERSION

http://dx.doi.org/10.1017/S1474746413000134

PUBLISHER

(c) Cambridge University Press

VERSION

AM (Accepted Manuscript)

LICENCE

CC BY-NC-ND 4.0

REPOSITORY RECORD

Padley, Matt. 2019. "Delivering Localism: The Critical Role of Trust and Collaboration". figshare. https://hdl.handle.net/2134/15271. 


\section{Social Policy and Society}

http://journals.cambridge.org/SPS

Additional services for Social Policy and Society:

Email alerts: $\underline{\text { Click here }}$

Subscriptions: $\underline{\text { Click here }}$

Commercial reprints: $\underline{\text { Click here }}$

Terms of use : $\underline{\text { Click here }}$

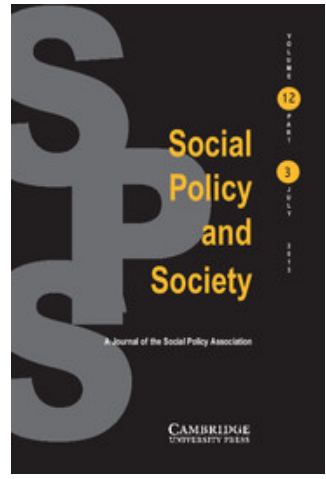

\section{Delivering Localism: The Critical Role of Trust and Collaboration}

Matt Padley

Social Policy and Society / Volume 12 / Issue 03 / July 2013, pp 343 - 354

DOI: 10.1017/S1474746413000134, Published online: 10 April 2013

Link to this article: http://journals.cambridge.org/abstract_S1474746413000134

How to cite this article:

Matt Padley (2013). Delivering Localism: The Critical Role of Trust and Collaboration. Social Policy and Society, 12, pp 343-354 doi:10.1017/S1474746413000134

Request Permissions : $\underline{\text { Click here }}$ 


\title{
Delivering Localism: The Critical Role of Trust and Collaboration
}

\author{
Matt Padley \\ Centre for Research in Social Policy, Loughborough University \\ E-mail: M.J.Padley@lboro.ac.uk
}

Debate regarding the relationship between individual and state has been prominent throughout the current UK government's term in office and localism has come to occupy a central role in current policy. This article argues that attempts to deliver this localist vision should focus on the critical role of social trust and that this is best developed through collaboration. The actions identified as necessary for delivering decentralisation are considered alongside a review of the view of localism articulated in Coalition policy. The article then explores collaboration and co-production as a means of strengthening social networks and delivering the promises of localism.

Keywords: Localism, trust, collaboration, co-production, public services.

\section{Introduction}

The Localism Act received Royal assent on 15 November 2011, providing the legal framework for 'the biggest transfer of power in a generation, releasing councils and communities from the grip of central government' (Department for Communities and Local Government, 2011a). The Act builds upon a commitment at the heart of the Coalition Agreement to 'completely recast the relationship between people and the state citizens empowered; individual opportunity extended - communities coming together to make lives better' (Cabinet Office, 2010a: 8); to divest Whitehall and central government departments of the power to micro-manage, impose one-size fits all solutions and set and measure performance against national targets (Department for Communities and Local Government, 2011b); and to give communities the freedom and powers necessary to help themselves rather than depending on local and central government for answers to their problems (Cameron, 2010, 2011).

The current Coalition government may have given a renewed momentum to localism, but the decentralising agenda and the drive to devolve power, decision making and responsibility to the lowest appropriate level was clearly evident in the policies of the previous Labour government throughout successive terms in office (Ellison and Ellison, 2006). Reforming our Public Services: Principles into Practice (Office of Public Services Reform, 2002) acknowledged a role for communities in the design and delivery of local public services and set out the relationship between effective delivery, devolution and delegation. A series of publications produced by HM Treasury focused on devolving decision making, encouraging local autonomy and flexibility and giving local communities greater freedom to determine service priorities (HM Treasury and Cabinet Office, 2004; HM Treasury, Office of the Deputy Prime Minister and Department for Trade and Industry, 2004). Working Together (Cabinet Office, 2009: 57) outlined plans for greater devolution and decentralisation to local councils, community groups and professionals, 
stressing the need for public services that were 'responsive to local circumstances and, crucially, harness the capacities of communities to identify and solve their own problems'.

While the commitment to empowering communities and increasing the active participation of citizens in local democracy and service delivery is neither new nor confined to one political philosophy, the recent promotion of localism, linked to abstract notions of a Big Society (Conservative Party, 2010; Cabinet Office, 2010b), ambitious plans for opening up public services (HM Government, 2011) and changes in local governance (Lowndes and Pratchett, 2012), raises a number of key questions and concerns. Specifically, the on-going policy commitment to localism raises questions about the articulation and application of this concept, how to ensure all communities have a role in shaping local democracy and public services, and the underlying networks and relationships that fundamentally underpin and support community involvement.

In light of these questions, this article seeks to articulate a way forward in terms of how the current localist vision may best be delivered. It begins with an overview of the Localism Act, looking at the kind of localism being promoted by the Coalition government and some of the implications of this for public service reform. The article then turns to focus on the key role of trust in delivering and developing strong civic communities, arguing that the limited attention given to trust in government discussions of localism and community empowerment to date is indicative of the difficulties of implementing policy and strategy that builds social trust and reciprocity. Reflecting the recent resurgence of interest in co-operation and growing calls for co-production to be seen as the means of delivering genuinely localised public services, this article argues that collaboration among individuals and within communities, both place-centred and technologically mediated, may be the best vehicle for developing social trust; within the localist context, trust is best established through collaboration, within and among communities, local democratic institutions and central government.

\section{The Localism Act and public service reform}

At the heart of the Localism Act are what have been termed the 'six essential actions of decentralising reform' (HM Government, 2010: 2). These actions are identified as the practical steps necessary for enacting and sustaining progress towards decentralisation, shifting power from a too centralised and bureaucratic state to local, empowered communities. The key actions outlined are: lifting the burden of bureaucracy that currently restricts local action; empowering communities to do things their own way, giving greater rights to individuals to influence and direct the development of their communities; increasing local control of public money, devolving more decisions about spending to a community level; diversifying the supply of public services, opening up delivery to a broader range of suppliers; increasing public access to government data and information, thereby enhancing financial transparency; and making local government more accountable to local people. These actions are predicated on structural reform in four related spheres (Department for Communities and Local Government, 2011b): within the structures of local government and governance; within the community and voluntary sector, with new rights for communities and individuals, including the right to challenge existing delivery of public services and the right for communities to bid to 
buy and run community assets; within planning legislation, including the introduction of neighbourhood plans; and, finally, across social housing, increasing local control of housing allocations and creating a national home swap scheme giving social tenants greater control over their own housing needs.

The rhetoric of reform under the Localism Act stresses the seismic shift in power from the centre to the local (Pickles, 2010). However, there is, rightly, a degree of scepticism and suspicion regarding the philosophy underpinning reform, the practicability of proposed changes and the implications of the reform process. The grand claims that have been made across government regarding the radical decentralisation of power are called into question by the 'raft of relatively small proposals' (Crowe, 2011: 656) through which the redistribution of power is to be achieved, and the assumption that simply scaling back bureaucracy and centralised structures of governance leads to the burgeoning of locally authored innovative solutions within communities is at best spurious and at worst in danger of reducing localism to a series of vague policy pronouncements from the centre (cf. Bunt and Harris, 2010; Urban Forum, 2010). To this end, both Westwood (2011) and Hildreth (2011) point to the gap between the rhetoric of localism and the concrete changes needed to ensure genuinely local economic growth, founded on local economic management and strategic development (Cox, 2010).

Amongst the implications of this current vision of localism is an increased inequality between those who may be left with a rudimentary level of public service provision and those who possess the necessary social, cultural and financial capital to develop and deliver local service innovation. The fundamental point here is that manufacturing greater rights for communities and increased opportunities for community involvement does not guarantee participation across the whole spectrum of society or mitigate the possibility that the powerful and affluent will dominate and shape local agendas and decision making (see Westwood, 2011; Escadale et al., 2012).

What is exposed here are the difficulties associated with a strong desire to radically curtail state intervention in public life, to replace big government with Big Society, while simultaneously encouraging and supporting greater societal participation; that is, the difficulty of marrying structural reform and relational reform. It has been suggested that the Coalition's version of localism is a founded on a distrust of 'big government' and on the liberal principle that less state activity is a prerequisite of greater societal participation (Lowndes and Pratchett, 2012). However, it is arguably the case that rather than limiting state activity and shrinking government, the Localism Act has preserved and/or reallocated key functions to central government that were once the domain of local government while simultaneously devolving responsibility, rather than power, to local communities below the level of local government (see Sear et al., 2011). Although it does not currently appear as a compelling and coherent 'solution', the current localist drive is, at least at a rhetorical level, a clear reaction against what has been characterised as the failed New Labour project. Coalition localism can be viewed as a response to perceived failings at three levels: a failure of democracy prompted by a loss of faith in elected officials which demands a state that is structurally and relationally more 'in touch' with the public; a moral deficit that has resulted in a broken Britain which demands a state that facilitates strong communities, neighbourhoods and families; and a fiscal failure, repeatedly laid at the feet of the Labour administration, that necessitates innovative (or less costly) ways of providing services that have historically been the preserve of the state. 


\section{What kind of localism?}

At its simplest, localism is about citizens having the right and ability to challenge their political and economic leaders, about the decentralisation of power and responsibility to frontline public service staff, service users, smaller local organisations and local business (Boyle, 2009). However, the lack of consensus and agreement regarding what localism represents means that for some the revival of interest in localism in recent years is part of a broader plan to improve market efficiency through decreasing state regulation and intervention (for example, Brenner and Theodore, 2002), while for others, localism represents a genuine, necessary and timely opportunity for increased citizen participation in shaping and delivering local public services and for engaging in local democracy (for example, Jenkins, 2004; Stoker, 2005, 2007).

Responses to current plans for localism echo these two broad views, with concern on the one hand that the community right to challenge to run public services is simply a means of opening the door to private providers who are better placed to tender and win contracts (Crowe, 2011), or that planning policy disproportionately favours developers over communities (Jenkins, 2011), while others highlight at least the potential for increased community empowerment (Westwood, 2011; Lowndes and Pratchett, 2012). There is much to question within the Localism Act and in the ways it is being played out. However, it remains the case that a renewed focus on the local, on the capacities and capabilities of communities, and on ways in which to strengthen participative democracy has created a climate in which there is both an appetite and a need to make sense of and deliver a more locally focused future.

Much of the scepticism regarding the purpose and outcomes of localism, still apparent more than a year after the Localism Act, results from the persistent lack of clarity regarding what is meant by the term. The Communities and Local Government Committee (2011: 3) have characterised the Government's approach to localism as incoherent and inconsistent, exacerbated by a mutable definition that has enabled individual government departments to shape localism according to their own priorities. The absence of a clearly articulated version of localism and the consequent confusion regarding 'who is responsible for what' has been added to by a number of prominent centrally determined policy decisions that appear to fly in the face of the prevailing localist rhetoric. Within education, central government decisions have resulted in the introduction of compulsory phonics testing for all six year olds and constraints on the choices individual schools are able to make over curriculum content. Perhaps less significantly but still running counter to the 'spirit' of localism, the repealing of government guidance regarding fortnightly bin collections can be seen as an example of centralism dressed up as localism (cf. Neill, 2011).

\section{Localism and public service reform}

The reform of public services, signalled as a key policy commitment by the Coalition (Cabinet Office, 2010b), is intimately entangled with the rhetoric and emerging realities of localism. The Open Public Services White Paper (HM Government, 2011) is marked throughout by the language of localism and decentralisation, particularly in its recurrent emphasis on the inadequacy of 'top-down prescription and centralisation' and the imperative to move control of public services as close to people as possible. Individuals and communities, rather than central and local government, are positioned as the principal 
determinants of the future shape of public services, with clear indications of the centrality of private and third sector partnerships in developing bespoke responses to service needs.

As with localism, the role of local government in delivering public service reform is less than clear. There is, for example, a stated desire to increase accountability and transparency at the level of local government (HM Treasury, 2010), while at the same time the role of elected representatives in shaping and providing services at a local level almost appears to be one of last resort. What is clear both within plans for public service reform and the localism agenda is the primacy of innovation and of the trust placed in locally initiated collaboration to deliver improvements in quality, efficiency and an increased fit between community needs and 'solutions'. In light of the prominence of the notion of collaboration within plans for localism and public service reform, and the lack of a convincing articulation of how best to deliver what has been promised by the Localism Act, the remainder of this article seeks to suggest a way forward for the current localist vision. In particular, it explores the critical role of social trust in delivering localism and how this may be established and maintained through collaboration, both at a general level and more specifically through co-production initiatives.

\section{The critical role of trust}

The importance of trust as a facilitator and product of community cooperation and collaboration has a long history (for example, Taylor, 1982, 1987; Luhmann, 1988; Etzioni, 1995). As far back as the 1960s, Jacobs (1961: 67) emphasised the links between the informal public life of cities, played out in communities and neighbourhoods, and the emergence of generalised social trust. For Jacobs the outcome of casual, public, local contact is 'a web of public respect and trust ... the absence of this trust is a disaster to a city street'. More recently, the work of Putnam $(1995,2000)$ on social capital and social trust has focused on the ways in which connections, interactions and formal/informal social networks foster community, engender shared values and thereby enable mutually beneficial collaboration and cooperation. Finding echoes in the Coalition commitment to localism and decentralisation, Putnam contends that the 'obliteration of traditions of independent civic engagement and a widespread tendency toward passive reliance on the state' (1995: 65, emphasis added) has contributed to a decline in shared social life, in communities coming together for the benefit of all individuals within that community, and ultimately in social trust; or as Blond (2010: 1) puts it, in the British context, to a broken Britain.

Putnam and others working in this area argue that social capital and social trust among individuals and within communities is greater where levels of civic and community engagement are greater. Levels of civic engagement are greater in more affluent communities where both individuals and communities are better resourced, and patterns and structures of engagement are entrenched. Central to this argument is the idea that it is engagement, collaboration and communication among individuals within communities that facilitates joint action, shared understanding and growing trust rather than necessarily the ceding of power from the centre downwards and outwards (cf. Michels and de Graaf, 2010).

The role of trust as an essential foundation for delivering localism is conspicuously absent from recent government discussions of both community integration (Department for Communities and Local Government, 2012) and safe active communities (Newlove, 
2012). Both reiterate the commitment to increasing community participation and engagement encapsulated in the Localism Act, and stress that the Act can function as a catalyst for 'encouraging communities to come together to do practical, everyday things' (Department for Communities and Local Government, 2012: 15). Missing from both, however, is a comprehension of the difficulty of accomplishing this task without a foundation of trust and strong social networks (Rowson et al., 2010). As Gilchrist (2009: 141) suggests:

Networking is effective for community development because it is personal, involving more than superficial connections devoid of emotional content. Networking is not about exploiting contacts in a manipulative or selfish way, but about establishing levels of trust, goodwill and mutual respect that run deeper than a sporadic and perfunctory exchange of information, business cards or favours.

Usefully casting light on this issue and providing examples of the ways in which communities with low social capital and low levels of social trust can coalesce are the Neighbourhood Challenge (NESTA, 2012) and Connected Communities (see Morris and Gilchrist, 2011) programmes. In reviewing progress to date, NESTA (2012: 4) are explicit in their aim for the Neighbourhood Challenge programme to illuminate the conditions 'beyond top-down regulation such as the Localism Act [that] can help create an enabling environment for community-led action'. The importance of social networks, built on trust and on-going relationship, is highlighted as an essential asset and as a catalyst in establishing local community-led innovation focused on shared priorities. Further stressing the importance of social networks, Morris and Gilchrist (2011: 5) state:

For government at any level to engage citizens and empower communities in decision-making and service delivery, policymakers and practitioners alike need to understand the factors that encourage and reduce people's motivation to get involved. Social networks are invaluable channels for recruiting volunteers and mobilising resources, as well as supporting all kinds of informal social interaction.

What is clear is that the Localism Act - and the numerous Coalition pledges to empower communities and increase the power of local people to shape their own lives needs to incorporate, first, a far clearer articulation of the importance of social networks built on, and in turn building, reciprocal trust and, second, more concrete plans for encouraging and facilitating the kinds of collaboration and cooperation necessary for greater local involvement in community life and service delivery (cf. Lowndes et al., 2006).

\section{Collaboration and co-production as the machinery of localism}

The importance of social networks for fostering and developing trust and reciprocity within communities needs to be recognised as central to delivering the promises of greater citizen and community participation and empowerment as set out in the Localism Act and in plans for public service reform. However, the successful delivery of the localist vision, decentralisation and public service reform ultimately will not hinge on top-down diktats about the need for local involvement or on legislative changes in local government 
coupled with state retrenchment. As we have already seen, there are indications that by the time of the next election in 2015, localism as it is currently promoted may have been responsible for allocating more powers to central government rather than directly enabling community development. What the success or failure of localism is more likely to rest on is the development of communities and neighbourhoods characterised by reciprocal relations, common commitments and shared lives: communities strong in social trust and capital. To put this another way, delivering localism depends on a rebuilding of the core social economy of family, neighbourhood, community and civil society (Cahn, 2000; Stephens et al., 2008; Boyle and Harris, 2009; Boyle, 2010), a reconstruction effort centred around collaboration, co-production and cooperation as the machinery of change and as the foundation for sustainable, strong, trusting communities. In this last section, the article looks at what collaboration can offer to both individuals and communities in terms of establishing and building social trust, before exploring the benefits to localism arising from co-production.

Collaboration, at its simplest, is about individuals, social groups or communities working together jointly to achieve an agreed end or result; and among individuals and within communities, both place-centred and mediated by technology, it has the potential to act as an important foundation for and catalyst of deeper levels of trust and co-operation. The decline in social trust and associational life over the past half century is a well-rehearsed narrative, at the heart of which is an account of increasing individualisation and diminishing connections between people and between people and the places in which they live and work. In a sense, the Big Society, and consequently localism, a key component of this nebulous idea, are a response to this acknowledged decline in relationships, mutuality and trust among individuals and with place. In order for the ends of localism to be delivered, it is critical that a means of re-instituting relationships, mutuality and trust is developed.

One possible starting point for this rebuilding may be found in the discernable shift in consumer behaviour witnessed in recent years. The growth and concomitant success of, for example, peer-to-peer redistribution websites, such as eBay and Freecycle, and gardenshare schemes such as Landshare, signal a move away from a system concentrated on private acquisition to one that publically connects and collectivises; a move away from individualised, hyper-consumption towards more collaborative forms of consumption focused on sharing assets and pooling resources. At the heart of what has been termed collaborative consumption (Botsman and Rogers, 2011) lies a recognition of the role that this shift in consumption patterns can play in rebuilding and establishing generalised social trust. Each of the examples above depend on individuals trusting and working with other individuals within communities, either virtual or material, for a common end. Landshare and the numerous other garden/land sharing initiatives in existence across the UK, for example, involve the sharing of a privately held resource ('green' space) with a 'public' that is at first unknown, to achieve a mutually determined purpose. Collaboration along these lines has been seen to have positive benefits for the individuals and communities involved: as part of the Transition Town Totnes initiative, garden sharing is believed to have helped 'build community-wide relationships and foster trust' (Transition Town Totnes, 2012). While there are limits in the extent to which these examples of collaboration can be seen as part of the delivery mechanism for localism, they do provide a basis through which to build and strengthen the social networks and trust recognised as central to sustainable community development (Gilchrist, 2009; Morris and Gilchrist, 2011). 
Collaboration, as it appears in a number of emerging locally established initiatives, can make a key contribution to the delivery of localism. With a clear accent on two-way transactions, it is a mechanism through which strong social networks may be established, built on reputation, trust and reciprocity and fostering relationships and a more connected sense of community. A key question however is how best to develop and build on the stronger social networks that can result from increasing levels of collaboration? One possible answer to this is through co-production. As a precursor to increasingly socially networked communities, collaboration can be seen as one means of laying the groundwork; co-production and cooperation may be viewed as the scaffold around which localism, with its emphasis on community empowerment and participation and allied public service reform, may be built. Since the emergence of the new localist drive following the UK parliamentary election in 2010, there has been a growing recognition of the value and importance of co-production and cooperation in developing and delivering effective local services, coalesced around an acknowledgement of service users as assets rather than 'problems' to be solved, a recognition of the significance of communities as places of complex and unregulated interactions capable of arriving at local solutions to big problems and an appreciation of the need for a different sort of policy-making process that enables rather than impedes cooperation (Cahn, 2000; Stephens et al., 2008; Boyle and Harris, 2009; Bunt and Harris, 2010; University of Birmingham Policy Commission, 2011; Leadbeater, 2012).

Co-production as a model of community and neighbourhood-led public service delivery is centred around the principal that public service providers need public service users in order for service delivery to operate effectively (Ostrom et al., 1973; Cahn, 2000). For Cahn (2000), often credited with developing the idea, co-production is founded on a recognition of people as assets and untapped resources, and a redefinition of work to include activities that historically have been described as domestic and non-work. At its heart, co-production emphasises the values of reciprocity and mutuality, challenging the conception of public service delivery as a one-way transaction, and of social networks, providing the 'human infrastructure' through which individuals and communities can and do come together with a common goal. In contrast to previous models of public engagement in service design and planning that have focused on consultation and 'democratising' decision-making, co-production seeks to involve individuals and communities of users in devising and delivering public and voluntary services; it is not simply about asking people what they think, it is about engaging people in providing the services that they and their communities, both virtual and material, use and need.

Defined in this way, co-production furnishes people with a reason and purpose to engage where they may previously have not. User involvement at the level of passive consultation has not historically led to radical changes in service delivery and has tended to be dominated by the loudest voices, the 'already involved' and the wellorganised communities of interest. There has consequently been little compelling reason for individuals falling outside of these categories to engage. User involvement at the level of actively co-producing services, however, entangles individuals in social networks whose purpose is to shape the form and function of local services and to arrive at locally authored mutual solutions. Building on existing communities of service users and social networks established through collaboration in other arenas, co-production potentially offers localism an inherently local, person and community focused means of delivering the transfer of power and empowerment that it promises. 
There are a growing number of examples of co-production in practice, particularly within the arena of health and social care, but also across a range of statutory and non-statutory public services. NESTA's People Powered Health programme has focused, for example, on establishing how co-production can support individuals with longterm health conditions. The programme has focused on supporting organisations which are bringing users, commissioners, practitioners and the wider community together to innovate in producing collaboratively designed and delivered services in, for example, mental health, physical and mental well-being and the co-location of core services. The New Economics Foundation are currently working with youth services in Lambeth and Cornwall to explore ways in which these can be commissioned and delivered in accordance with the principles of co-production. What unites these examples is a commitment to the principle that users are best placed to define and determine the shape and nature of the services they receive at a local level. Another common thread running through these is a clear sense that a focus on co-producing services brings gains in terms of breaking down the barriers and strengthening trust between service 'users' and 'providers', and creating resilient social networks marked by reciprocity. In other words, this is localism in action: individuals coming together around a common purpose, working collaboratively to produce locally focused solutions and in so doing developing social capital. What both a greater emphasis on collaboration as a foundation of local action and governance and co-production as a means of developing and delivering public services offer is a starting point for a clearer formulation of what localism may look like away from Whitehall pronouncements and 'Big Society' rhetoric. What localism offers to a renewed focus on collaboration and to co-production as a model of public service innovation and delivery may be a context and climate in which there is increased appetite, legislative support and a greater need for new methods of service delivery.

\section{Conclusion}

This article has provided an examination of the localism agenda as it is being advanced by the UK Coalition government. It has argued that in order to be successful, decentralisation and community empowerment need to be undergirded by significant levels of social trust built through and upon collaboration and co-production. Although the Localism Act has instituted a range of amendments to local structures of governance and captures something of the government zeitgeist related to devolving and ceding power from the centre, there remains a lack of a clear articulation of how the Act will deliver on its commitments. Moreover, there is a concern that the focus on localism will serve to reinforce existing inequalities and, most cynically, that it does little more than provide a justification for fiscal restraint through vague, unworkable notions of community empowerment. However, despite the strong basis for scepticism, new opportunities and possibilities are doubtless being opened up as the balance between state and citizens is rethought and adjusted. It is critical, if these opportunities are to be of mutual benefit, that the discussion moves beyond rhetoric and broad brush strokes to meaningfully work with individuals, groups and communities to radically rethink what it means to make policy and how this is done, and to ensure that the power to shape the future rests not on radical reform but on relationships. One way in which this relational reform may be achieved is through a greater use of existing collaborative networks and a genuine transformation in power 
relations between users and providers of public services brought about by a broader deployment of co-production as a model of service delivery.

\section{References}

Blond, P. (2010) Red Tory: How Left and Right Have Broken Britain and How We Can Fix It, London: Faber \& Faber.

Botsman, R. and Rogers, R. (2011) What's Mine Is Yours: How Collaborative Consumption Is Changing the Way We Live, London: Harper Collins.

Boyle, D. (2009) Localism: Unravelling the Supplicant State, London: New Economics Foundation.

Boyle, D. (2010) 'Local economics and co-production', Development, 53, 3, 319-24.

Boyle, D. and Harris, M. (2009) The Challenge of Co-production, London: NESTA.

Brenner, N. and Theodore, N. (2002) 'From the new localism to the spaces of neo-liberalism', in N. Brenner and N. Theodore (eds.), Spaces of Neo-Liberalism: Urban Restructuring in North America and Western Europe, Oxford: Blackwell, pp. v-xi.

Bunt, L. and Harris, M. (2010) Mass Localism: A Way to Help Small Communities Solve Big Challenges, London: NESTA.

Cabinet Office (2009) Working Together: Public Services on Your Side, London: Cabinet Office.

Cabinet Office (2010a) The Coalition: Our Programme for Government, London: Cabinet Office.

Cabinet Office (2010b) 'Building the Big Society', http://www.cabinetoffice.gov.uk/sites/default/files/ resources/building-big-society_0.pdf [accessed 10.08.2010].

Cahn, E. (2000) No More Throw-Away People: The Co-Production Imperative, Washington: Essential Books.

Cameron, D. (2010) 'Our Big Society agenda', Speech, 19 July 2010, http://www.conservatives.com/ News/Speeches/2010/07/David_Cameron_Our_Big_Society_Agenda.aspx [accessed 27.01.2012].

Cameron, D. (2011) 'Building a bigger, stronger society', Speech, 23 May 2011, http://www.conservatives. com/News/Speeches/2011/05/David_Cameron_Building_a_bigger_stronger_society.aspx [accessed 30.01.2012].

Communities and Local Government Committee (2011) Localism:Third Report of Session 2010-12 Volume 1, HC547, London: The Stationery Office.

Conservative Party (2010) Building a Big Society, London: Conservative Party.

Cox, E. (2010) Five Foundations of Real Localism, Newcastle: IPPR.

Crowe, J. (2011) 'The government's plans for decentralisation and localism: a progress report', The Political Quarterly, 82, 4, 651-7.

Department for Communities and Local Government (2011a) 'Power shift from Whitehall to communities gets underway', press release issued by the Department for Communities and Local Government, 16 November 2011, http://www.communities.gov.uk/news/newsroom/2030130 [accessed 25.01.20121.

Department for Communities and Local Government (2011b) A Plain English Guide to the Localism Act, London: Department for Communities and Local Government.

Department for Communities and Local Government (2012) Creating the Conditions for Integration, London: Department for Communities and Local Government.

Ellison, N. and Ellison, S. (2006) 'Creating "opportunity for all?" New Labour, new localism and the opportunity society', Social Policy and Society, 5, 3, 337-48.

Escadale, W., Jackson, M. and Speeden, S. (2012) Responsible Reform: Open Public Services for All, Manchester: Centre for Local Economic Strategies.

Etzioni, A. (1995) The Spirit of Community, London: Fontana.

Gilchrist, A. (2009) The Well-Connected Community, 2nd edition, Cambridge: Polity Press.

Hildreth, P. (2011) 'What is localism, and what implications do different models have for managing the local economy', Local Economy, 26, 8, 702-14. 
HM Government (2010) Decentralisation and the Localism Bill: An Essential Guide, London: The Stationery Office.

HM Government (2011) Open Public Services, CM8145, London: The Stationery Office.

HM Treasury and Cabinet Office (2004) Devolving Decision Making: 1 Delivering Better Public Services Refining Targets and Performance Management, London: HM Treasury.

HM Treasury, Office of the Deputy Prime Minister and Department for Trade and Industry (2004) Devolving Decision Making: 2 Meeting the Regional Economic Challenge - Increasing Regional and Local Flexibility, London: HM Treasury.

HM Treasury (2010) Spending Review 2010, CM7942, London: The Stationery Office.

Jacobs, J. (1961) The Death and Life of Great American Cities: The Failure of Town Planning, Harmondsworth: Penguin Books Ltd.

Jenkins, S. (2004) Big Bang Localism: A Rescue Plan for British Democracy, London: Policy Exchange.

Jenkins, S. (2011) 'This localism bill will sacrifice our countryside to market forces', The Guardian [online], 28 July, http://www.guardian.co.uk/commentisfree/2011/jul/28/localism-bill-sacrifice-countrysidemarket [accessed 30.08.2011]

Leadbeater, C. (2012) It's Cooperation Stupid, London: IPPR.

Lowndes, V. and Pratchett, L. (2012) 'Local governance under the Coalition government: austerity, localism and the "Big Society"', Local Government Studies, 38, 1, 21-40.

Lowndes, V., Pratchett, L. and Stoker, G. (2006) 'Diagnosing and remedying the failings of official participation schemes: the CLEAR framework', Social Policy and Society, 5, 2, 281-91.

Luhmann, N. (1988) 'Familiarity, confidence and trust: problems and perspectives', in D. Gambetta (ed.), Trust: Making and Breaking of Cooperative Relations, Oxford: Blackwell.

Michels, A. and de Graaf, L. (2010) 'Examining citizen participation: local participatory policy making and democracy', Local Government Studies, 36, 4, 477-91.

Morris, D. and Gilchrist, A. (2011) Communities Connected: Inclusion, Participation and Common Purpose, London: RSA.

Neill, B. (2011) 'Improving frontline rubbish and recycling services for family homes', Speech, 15 June 2011, http://www.communities.gov.uk/speeches/newsroom/1923924 [accessed 04.01.2012].

NESTA (2012) Neighbourhood Challenge: Learning from Innovative Communities, London: NESTA.

Newlove, H. (2012) Building Safe, Active Communities: Strong Foundations by Local People, http://www.communities.gov.uk/documents/communities/pdf/2088494.pdf [accessed 15.02.2012].

Office of Public Services Reform (2002) Reforming our Public Services: Principles into Practice, London: Office of Public Services Reform.

Ostrom, E., Baugh, W., Guarasci, R., Parks, R. and Whitaker, G. (1973) Community Organisation and the Provision of Police Services, Beverly Hills: Sage Publications.

Pickles, E. (2010) 'Queens Speech Forum', Speech, 11 June 2010, http://www.communities.gov.uk/ speeches/corporate/queensspeechforum [accessed 30.01.2012].

Putnam, R. (1995) 'Bowling Alone: America's declining social capital', Journal of Democracy, 6, 1, 65-78.

Putnam, R. (2000) Bowling Alone: The Collapse and Revival of American Community, New York: Simon $\&$ Schuster.

Rowson, J., Broome, S. and Jones, A. (2010) Connected Communities: How Social Networks Power and Sustain the Big Society, London: RSA.

Sear, C., Parry, K., Ares, E. and Bennett, O. (2011) Localism Bill: Local Government and Community Empowerment, Bill No. 126 of 2010-11, Research Paper 11/02, London: House of Commons Library.

Stephens, L., Ryan-Collins, J. and Boyle, D. (2008) Co-production: A Manifesto for Growing the Core Economy, London: New Economics Foundation.

Stoker, G. (2005) What is Local Government For?: Refocusing Local Governance to Meet the Challenges of the 21st Century, London: New Local Government Network.

Stoker, G. (2007) New Localism, Participation and Networked Community Governance, University of Manchester: Institute for Political and Economic Governance.

Taylor, M. (1982) Community, Anarchy and Liberty, Cambridge: Cambridge University Press. 
Taylor, M. (1987) The Possibility of Cooperation, Cambridge: Cambridge University Press.

Transition Town Totnes (2012) 'Gardenshare' http://www.transitiontowntotnes.org/groups/food-group/ gardenshare/gardenshare-further-info/ [accessed 12.12.2012].

University of Birmingham Policy Commission (2011) When Tomorrow Comes: The Future of Local Public Services, Birmingham: University of Birmingham.

Urban Forum (2010) 'Reaction to the Localism Bill' http://www.urbanforum.org.uk/files/ufpublic/2010 12_reaction_to_the_localism_bill.pdf [accessed 30.01.2012].

Westwood, A. (2011) 'Localism, social capital and the "Big Society"', Local Economy, 26, 8, 690-701. 